\title{
A Model of Creating Instructional Materials Based on the School Curriculum for Indonesian Secondary Schools
}

\author{
Eny Syatriana, Djamiah Husain, Haryanto, and Baso Jabu \\ 1. YPUP, School of Teacher Training and Education, Makassar Indonesia \\ 2. Post Graduate Studies, State University of Makassar, Indonesia. \\ *E-mail of the corresponding author : enysyatriana@yahoo.com
}

\begin{abstract}
English performance and competence of Indonesian secondary school students are low. This may result from poor instructional materials so that they do not meet the students' need; and this should be the main objective for English teachers to improve the learning outcome of students. The purpose of this study is to develop a model of creating instructional materials based on school curriculum. Creating a model of designing instructional materials is part my developmental study consisting of need analysis, design, development, implementation, and evaluation; this paper discuss need analysis to create a model of creating instructional materials through deep discussion among teachers of secondary schools. The result presents some main procedures need analysis, designing, developing the materials, implementation, and evaluation (ADDIE). The other components include purpose, school curriculum, application of pedagogical aspects, contextualization. The model is derived from ADDIE, Dick and Carey, Jolly \& Bolitho, and Instructional Development Learning system (IDLS). Instructional materials with different strategies and various materials improve the English achievement of the students. Both teachers and students argue that appropriate instructional materials are good enough to be used in the teaching and learning process to increase the English achievement of the students.
\end{abstract}

Keywords: Development; teaching model; English for secondary school students; competence.

\section{Introduction}

Indonesian students have low English achievement (Hamra \& Syatriana, 2012: Ratna, 2013: Endang 2013). This should be the main objective for the English teachers and Indonesian government to participate in solving this problem. In reality, the Indonesian government in this case the Minister of Education and Culture has created a lot of efforts such as upgrading the teachers' qualification through training and education, conducting workshops implementing certain teaching strategies, and teachers' group discussion at the schools, but the English learning outcome is still far from the expectation of school curriculum (Syatriana, 1998; Kwelju, 2003).

In the teaching and learning process at schools, different kinds of instructional materials: newspaper, magazines, and course books (Cuban, 2010) used by teachers, but most of them do not match to school curriculum; most of them are commercial-based books.

The low English proficiency of the students may result from various aspects. These include: (1) the monotonous teaching strategies implied by the teachers in the classroom, (2) the lack of teaching facilities or media, (3) the linguistics competence, (4) the learning habits, interest, attitude, and (5) ineffective instructional materials (Hamra, 2003).

Not many teachers facilitate their teaching with appropriate teaching media; they are not aware of the use of the teaching media. They teach totally based on textbooks. They are reluctant to prepare appropriate media in their teaching and learning process. They know the importance of the media, but they are too lazy to prepare them. This is a real situation that happens at almost all schools. The ineffective instructional materials also may cause the low learning outcome of the students.

Instructional materials which are based on the curriculum and students' need may increase students' learning outcome and obtain the purpose of the school curriculum. The present study plans to design a model of developing instructional materials to help students meet their English proficiency based on the school curriculum. The curriculum which is designed by the school can help teachers in their teaching and learning process. Every teacher is expected to develop syllabi, lesson plans, instructional materials based on the school-based curriculum (2006). In reality, not all English teachers are able to develop instructional materials. This is also the reason why this paper was presented. The schools have to design syllabi that have components of competency standards, basic competency, instructional materials, learning objectives, indicators, evaluation, allotted time, and learning resources for each subject at a school.

A number of researchers have discussed good strategies in designing instructional materials to be effective in promoting learners' interest, Stewner Manzanares, Chamot, O’malley, Krupper \& Russo, 1985; Weden \& Rubin, 1987; Oxford, Talbott \& Halleck, 1990). In addition, strategy in designing instructional materials helps teachers become more aware of their students' needs and improves the relationship between the instruction and students styles and strategy. 
Instructional materials or coursebooks should provide teachers and learners with the arrangement of professionally developed materials, allowing teachers to spend their valuable time more on facilitating learning materilas (O’Neil,1982; Hutchinson and Torres, 1994; Edger \& Wharton, 1998) say that coursebooks are used flexibly, and they can be adapted and suplemented to meet the needs of spesific classes. Brady \& Kennedy (1999) state the disadvantages for the use of coursebooks: (1) Coursebook fulfills a wide range of practical needs, particularly in a context where English is being taught in a non-English-speaking environtment. (2) The coursebook helps to provide a route map for both teacher and learner, making it possible for them to look ahead to what will be done in a lesson as well as to look back on what has been done. (3) Coursebook provides structure and predictability, which helps participants in social interactions like lessons, a safe base, a platform for negotiation and exploration. (4) By dealing with a certain amount of routine work for teachers, the coursebook frees them to attend to more important aspects of lesson planning (including materials adaptation and supplementation) and to concentrate on using their creative skills. (5) The coursebook is expected to meet the students needs, specifically to the instruction, mastering, and understanding its content. The book will be designed to make learning for the students as easy as the students use it in learning. Later, it is hoped that the course book may help the students to reach the Standard Point Criteria among various of school group levels. Chou (2010) presented some disadvantages of English course books, among others: (1) the large number of activities of "questions and answers" in the course books may cause many students find the learning process boring and uninteresting. The reading selections mostly international level which do not touch the local context Tomlinson, 1998).

Based on the previous description, this paper intends to design English instructional model for high school teachers with the application based on the school curriculum for the purpose of students learning English effectively so that they have good English language skills in accordance with the school curriculum.

\section{Language Skills}

Atkinson (1985) shared four basic skills that must be mastered by the learner of languages, namely: listening, speaking, reading and writing. Writing and speaking is the output while reading and listening are inputs that must be trained to produce to obtain good output. Writing as a skill in languages is absolutely always to get more attention in terms of improving the quality of the writing.

The ability of students to communicate can be seen from two aspects, namely: communication verbal and written communication. In oral communication, teachers must equip the students with good pronunciation; on written personal communication, teachers must equip the students with knowledge of correct writing and spelling. Errors in pronunciation and spelling may cause misunderstanding.

In learning some languages, there are two main skills that need to be controlled, namely: (1) Skills of receptive and productive skills. Receptive skill: listening skills and reading skills, (2) productivity skills consist of: speaking skills and writing skills. Here is the explanation of each skill:

\subsection{Listening}

Listening means an effort to gain understanding of the hearing. As with reading, there are several important aspects or skills which need to be in listening, namely: (1) to understand the subject matter which presented by the speaker, (2) to understand in details the basic thoughts that is expressed by the speaker. A good observer uses records retrieval skills (note taking) while listening to a description.

2.1.1. The process of listening

Listening is not just to hear what someone said, but heard by Lyman K. Steil (1983) has three important components, namely: (1) Interpretation of what someone said, the interpretation of the listener can really be incorrect but could also depend on how far he has knowledge of the hearing, (2) evaluation is to weigh the information and decide how to use it, and (3) responding based on what is heard, understood, and evaluated.

In the process of listening, audiences are sometimes unable to process the sound is heard from speakers such as rooted in physiological processes (hearing), the basic tendency of psychological (perception) and idiosyncrasies (listening habits) listener itself. (1983). At the hearing, we must strive to hear the message which is delivered, so conversation can be evaluated, responded. The perfect understanding can be obtained properly.

2.1.2. Listening Skills

Many learners cannot understand or comprehend what is heard; therefore, they cannot use techniques or listening skill well. Listening skills can be enhanced or repaired through the exercise with good technique. Hearing is not without purpose or just passive. Whether hearing aims to enjoy what was said or how to say something, get a sense of a message, or to evaluate what the facts, hear the good requires a positive attitude (Andrew \& Carolyn (1980). People listen well as they want to, not because they have to. Listening to the understanding or evaluation is more complex than the hearing to enjoy. The speaker does sometimes not convey his ideas in a complete format, they would beg the listener to complete it based on knowledge and experience. The expectancy completes the speaker's information or ideas to a barrier to the listener's understanding. 
In learning English, students are expected skilled in listening to the words, phrases, sentences, simple oral text, a conversation between two people or more and can give a precise meaning. The precision gives the meaning that a lot depends on the basic knowledge students possessed. Students who listens to a description of the supermarket and know a lot about the supermarket probably because he lives in the city, then it will be easy to answer questions about the supermarket.

2.2 Speaking

Speaking is a skill in conveying information, ideas or concepts to the listener. To understand the review easily by the listener, the speaker usually uses a certain procedure in conveying his ideas. Speakers always strive to present the information that can be easily understood by listeners. There are some important things to pay attention for speakers of English in order to make the message can be understood that was delivered, by his audience well, namely: (1) The utterance or pronunciation of speaker should be clear, and accurate. Mastery of language is not only determined by how many or large the mastery of grammar but also how accurate and clear the speaker say the words, phrases, or sentence by sentence in the speech of information, (2) to states the ideas in complete sentences. Main ideas are the most important information to be conveyed by the speaker, (3) to develop ideas by providing explanations, descriptions or examples, (4) to use sentences which are easy to understand by his audience. The sentences are to be used should be adapted to the level of student ability, and (5) to use the appropriate sentences intonation and gestures (body movements or eye contact) is to help listener's understanding.

2.3 Reading

Reading is a complex cognitive activity that is indispensable for adequate functioning in society. To enter the present literate society, students must know how to learn from reading. Successful reading, especially in the higher grades, includes critical thinking and studying. Students are required to understand the meaning of text, critically evaluate the message, remember the content, and apply the new found knowledge flexibly (Brown \& Campione, 1990; Pressley, 2000). As students advance in their studies, they need to be able to rely on their ability to independently understand and use information gleaned from text. Text becomes the major, if not the primary, source of knowledge; reading is a mediating process that involves composition of meaning (Smagorinsky, 2001).

Reading is one of the four language skills that is necessary to be owned by anyone who wants to improve science. Mikulecky \& Jeffries (1996) states that reading is an appropriate tool to promote life-long learning. By teaching students to read, it means to give them the skills to obtain or increase their knowledge so that he can be full of students with the large insight.

2.3.1 Meaning of Reading

Reading is a process of language and communication, which is a process which provides the opportunity for readers to make contact and communication with various ideas (Dechant, 1982). Therefore, reading always involves interaction between writer and reader. Reading is an act of communication processes that starts from the mind of the writer that is expressed on paper through symbols. Without a reader, communication through writing on paper might not happen. Reading requires thought and creative activity. These activities require knowledge and skills essential for reading which held by the reader. Ability and skill in question is the ability and skill to recognize words, to understand the meaning of the word, to understand what is being read, to organize and remember, to associate information, and to read aloud to be understood by the listener. Therefore, reading requires high order thinking. Reading requires the communication of the message and understanding which consists of several levels of understanding. They start from the level of verbal understanding to the level of interpretive concrete understanding to the abstract, and from the simple level of evaluation to the level of complex evaluation. It involves interaction between reader and text characteristic, which work on each other to form meaning.

In general, the definition of reading consists of two categories. The first category views reading as a decoding process, where readers are taught to write the words. The second category is to read to find meaning (reading for meaning), where the emphasis is on reading for comprehension. The comprehension in reading is very difficult to give restrictions, as proposed by Robinson (1980) state that there is no certain definition of reading comprehension. Vacca and vacca (1986) states that to read "involves the comprehension and interpretation of ideas symbolized by the written or printed page." Emerald Dechant (1982) provides a definition of reading as an "interpretation of the printed page." In the process of interpretation, the reader is often difficult to communicate the symbol graphic to their experience. In addition, the interpretation also requires recognition and perception. Both Vacca \& Vacca and Smith \& Dechant agreed that reading requires a prediction, decision, analysis, synthesis, selection, and evaluation of the public. In this connection, the reader is challenged by the author, but on the contrary, he is authorized to give meaning or significance to the author's writing based on their opinion. Although many differences about the definition of reading, most reading experts agree that the reading process include: (1) letter and word recognition, (2) understanding of the text, and (3) reaction and assimilation of new 
knowledge from reading texts with experience / knowledge possessed reader. In general, lecturers reading (reading lecturers) have argued that reading is the interaction between writer and reader. To understand the message text, the reader must observe, interpret, and evaluate reading materials. This process varies in each reader relies on reader knowledge of the content of the text and purpose of reading. The process of observation, interpretation, and evaluation occurs quickly in the mind of the reader. The amount of time spent is not an essential element, but the important thing is active participation from readers.

2.3.2 Reading Comprehension

In general, reading comprehension is a text information acquisition. If the information is not prepared or processed means of understanding does not occur. Therefore, the reading means understanding. Comprehension in reading involves the relationship between meaning and symbol of the word, the selection of the precise meaning according to context, the organization of meaning, and the ability to give arguments as well as capturing the idea. Therefore, reading in the sense understood in essence is thinking (Vacca \& Vacca, 1981). Understanding is a process of thinking through reading. Understanding that rely on basic cognitive and intellectual ability, background experience, including mastery of vocabulary, knowledge about concepts and ideas, and language skills including knowledge of morphology and structure of sentences.

Many activities in reading comprehension are based on three levels of reading comprehension; third level of understanding is usually called literal level of understanding (on the lines), inferential comprehension (between the lines, and critical understanding (beyond the lines). It can be argued that all three levels of this sequential hierarchical; literal comprehension is easier than inferential comprehension and inferential comprehension easier than a critical comprehension. Next Lapp \& Flood (1986) suggested three levels of comprehension, namely:

2.3.3 Literal comprehension

Uunderstanding based on facts that exist in the text where the reader can be expected to mention or remember the facts in the text. Thus, the literal comprehension questions are easy to answer because the answers are stated by the writer.

2.3.4 Inferential comprehension

On this understanding the reader is expected to integrate information and draw conclusion (inference). Readers are expected to know not only what the authors say, but also what the author intended from being said.

In the literal comprehension the readers read on the line, in inferential comprehension readers read between the lines. At literal comprehension readers identify the important information, at inferential level readers look at the link containing information and make inference based on that relationship.

2.3.5 Critical comprehension

At a critical comprehension of the reader is expected to use the information to express opinions and form new ideas. At this level, readers are invited to read on the other side of the line (beyond the lines). Therefore, at this level of understanding the reader should be able to find new ideas based on existing information, as expressed by (Longman, 1985) stated that the discovery of an idea or concept "is in its essence a matter of rearranging or transforming evidence in such a way that one is enabled to go beyond the evidence so reassembled to additional new insights"

\subsection{Writing}

Writing that cannot be separated from human life is a form of communication where a person can express ideas, feelings, or knowledge. Learning to write is an important activity throughout the learning process experienced by learners.

As in the skills of reading, learner in writing also needs to think of thought (main idea) that will be delivered, how the basic thoughts of supporting (supporting details) is formulated, and how details are disclosed in supporting these basic thoughts in conveying the message or information. In general, writing component of the mechanism consists of content's organization, grammar, vocabulary, and mechanics of writing.

\section{Instructional Model}

The word instruction is a science and the instructional design is a technology of the science (Merriell, 1996). It is a procedure which is not governed by any natural laws, teachers should be creative to produce instructional design model to improve their teaching and learning process. In other hand, it must relate to scientific principles of instructional strategies. Instruction should allow students to do appropriate learning activities; therefore, teachers should help students control the learning activities that promote learning. Merriell (1996, p. 2) stated that "Instructional design is the technology of creating learning experience and learning environments which promote these instructional activities".

\section{Creating Instructional Model}

There are many models of writing instructional materials, among others: 


\subsection{ADDIE model}

ADDIE model is the most common model to create instructional materials. ADDIE means Analyze, Design, Develop, Implement, and Evaluate. Watson, et al. in Ampa (2013) presents the figure in the following:

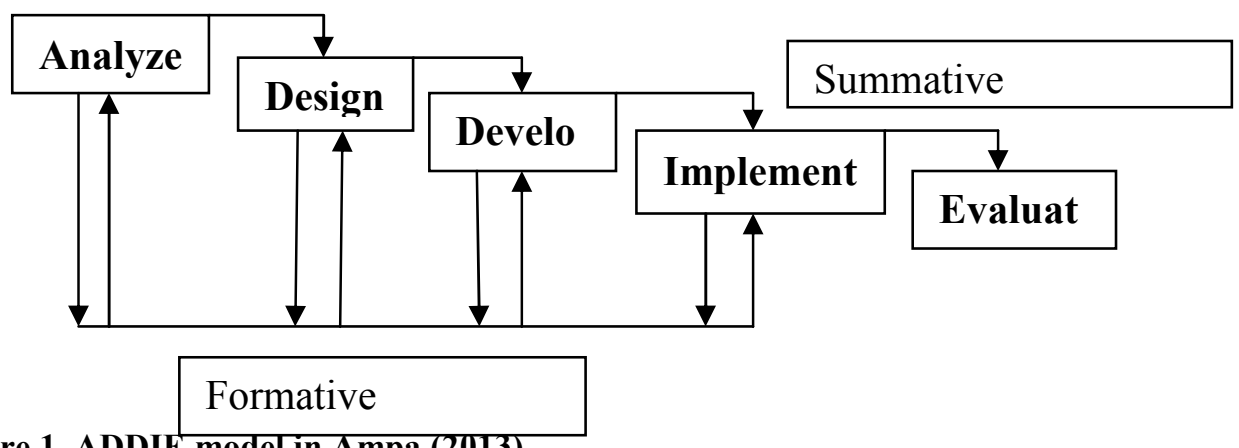

Figure 1. ADDIE model in Ampa (2013)

Analysis refers to the gathering of information about the students' English competence and the use of existing course book. What is the students' expectation about the English competence and the course books, and what is the purpose of learning English. Design refers to the creation of models of instruction in relating to language and learning theories and writing design of the instructional materials. Development refers to writing activities for implementation, the blueprints in the design phase are assembled. Implementation refers to the use of all materials and to test if the materials are appropriate for the students. Evaluation refers to the evaluation of the materials and the achievement of the expected goal.

4.2 Dick and Carey Model

Another popular model of instructional design is Dick and Carey Systems Approach Model. The model was first published in 1978 by Walter Dick and Lou Carey in their book, "The Systematic Design of Instruction". Dick and Carey stated that "Components such instructor, learners, materials, instructional activities, delivery system, and learning and performance environments interact with each other and work together to bring about the desired student's learning outcome". Dick and Carey (2005) presents procedures of the model as in the following:

a. Identify instructional goals.

b. Conduct instructional analysis.

c. Analyze learners and contexts.

d. Write performance objectives.

e. Develop assessment instruments

f. Develop instructional strategies.

g. Develop and select instructional materials.

h. Design and conduct formative evaluation of instruction

i. Revise instruction.

j. Design and conduct summative evaluation.

4.3 Instructional Development Learning system IDLS)

Instructional development learning system is another model of instructional design which was first published in 1970 by Peter J. Esseff and Mary Sullivan Esseff in their book, entitled IDLS-Pro Trainer 1: "How to design, develop, and validate instructional materials". The procedures of the model are in the following:

a. Design a task analysis.

b. Develop criterion tests and performance measures.

c. Develop interactive instructional materials.

d. Validate the interactive instructional materials.

4.4 Jolly and Bolitho Model

Jolly \& Bolitho's Model in Tomlinson (1998, p. 98 ) present the steps of instructional material development, as follows: 
Identification of need for materials

Notes:
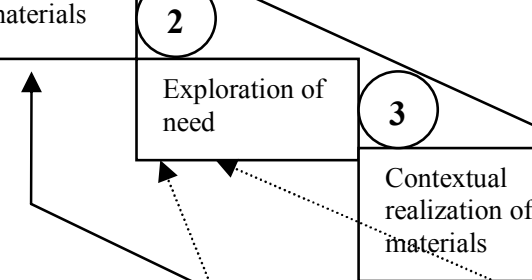
realization of materials

ynamic path Optional steps and feedback loops

Figure 2: Model design from Jolly \& Bolitho in Tomlinson (1998)

In the identification, the material developer: the teachers and learners need to identify the current fenomena of the teaching and learning process and they are expected to create new teaching materials. In the next step, material developers need to explore the area of problem in the case of language forms and functions. Then, they have to prepare contextualization of the materials, that is the local content area of the materials to be involved in reading, writing, listening, and speaking resources. Next, pedagogical realization involve the use of instruction and appropriate exercises and activities, and the last the physical production of the materials in the form of course books including the layout, visual, and size of the books. The writer gathered information from six English teachers from three schools about the students' English proficiency and the use of the existing instructional materials or course book used by the teachers at the schools. The model of creating instructional materials in figure 4 was derived from the previous discussed models.

4.5 Model of creating new instructional materials

Since this paper is part of my dissertation the writer only presents a model of creating instructional materials through deep discussion among six English teachers at three secondary schools in Makassar city, Indonesia. The Instructional Material Development Based on School Curriculum (IMDSC) is based on the components from ADDIE model, Dick and Carey, IDLS model, and Jolly \& Bolitho in Tomlinson (1998). The main procedure is based on ADDIE model and some details of developing instructional materials are based on IDLS and Jolly \& Bolitho, Dick and Carey, and the School Curriculum as in the following figure: 


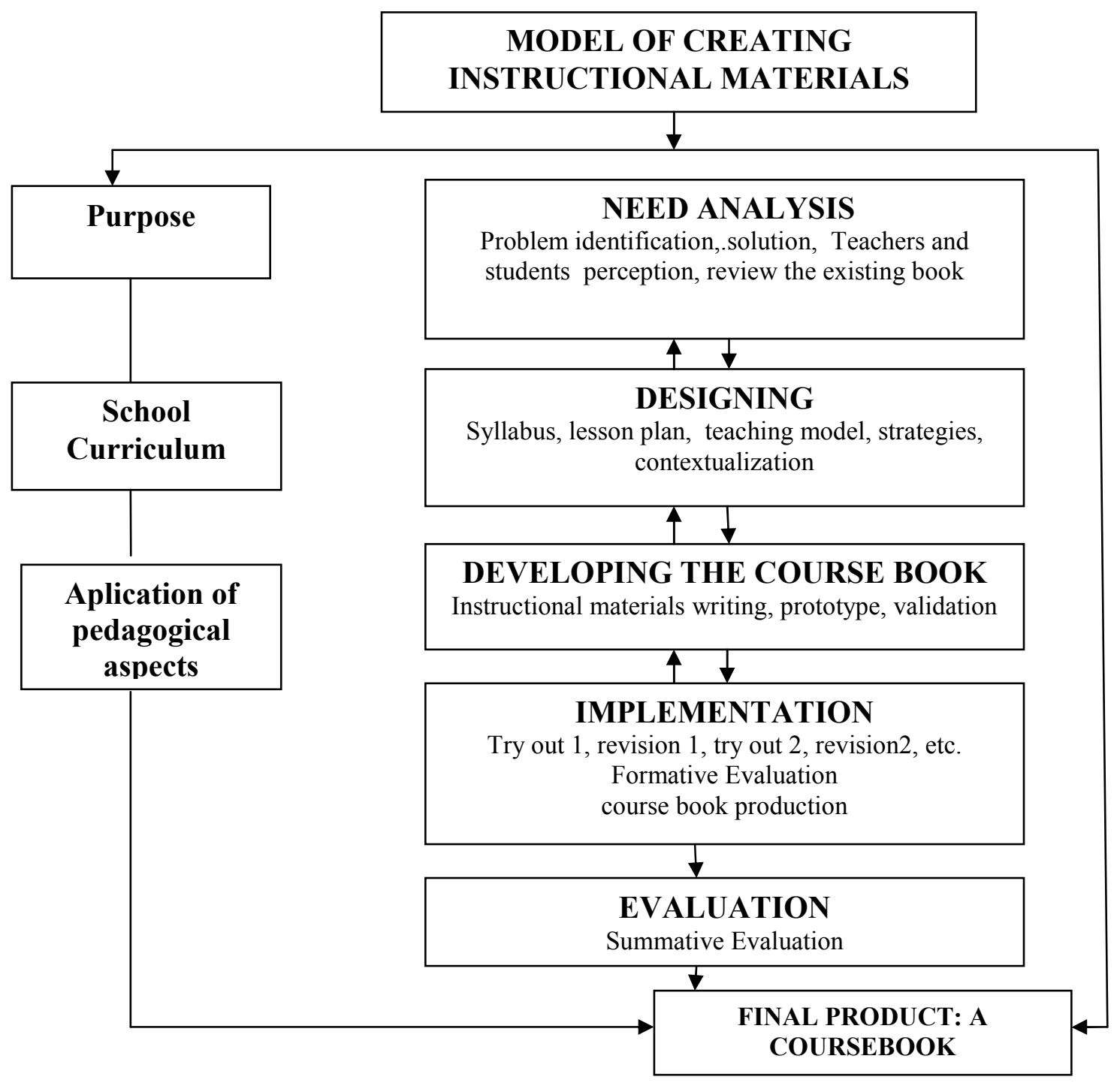

Figure 3. The Instructional Material Development

Based on the School Curriculum (IMDSC)

Figure3. Indicates that there are five main components (need analysis, design, development, implementation, evaluation) and then come to Final Product). Other components are purpose, school curriculum, application of pedagogical aspects. In each component there some sub components that need to be considered in creating instructional materials, which consist of Need Analysis: problem identification and its solution, teachers and students' perception, what the students want, and review of the existing instructional materials, etc. Presenting the purpose of writing is primary importance since this is the final expectation. Teachers want the students to get the specific or the performance objectives of their teaching. Thus, writing first the performance objectives is very essential in creating instructional materials for the students. Teachers should also be able to choose appropriate teaching strategies based on the selected teaching materials. Teaching process should be evaluated through formative test, and summative test is administered to see the learning outcome of the students.

\section{Conclusion and Suggestion}

There are some conclusions and suggestions coming from the previous descriptions:

a. The good learning outcome is influenced by various components, one of them is the instructional material used by the teachers. The materials should meet the students' need. Thus, instructional materials should be designed based on the students' need.

b. There is no standard way in designing instructional materials; therefore, teachers should be creative in developing instructional materials based on the curriculum and the students' need. 
c. Instructional materials or course books based on the local content make students easy to comprehend the materials. The course book should present not only the international contents, but also the national or the local one.

d. Appropriate instructional materials or course books may help students to improve their language skills completely based on the school curriculum.

e. Different kinds of instructional materials may be an alternative for teachers in choosing the best one for their teaching and learning process.

f. Writing purpose should be stated before writing the instructional materials, because this will lead the writing designer to have a complete writing; involving school curriculum in designing instructional materials will help students to get the expected objectives of teaching materials; considering and applying pedagogical aspects will help students' learning.

\section{References}

Andrew, R. Wolvin \& Carolyn, Gwynn Coakley. (1980). Listening instruction (Annandale,VA:Speech Communication Association, TRIP Series.

Ampa, A.T. (2013). Developing multimedia learning materials for speaking skills based on contextual teaching and learning. Unpublished dissertation. Postgraduate Program. State University of Makassar

Atkinson, R. H., \& Longman, D. G. 1985. Reading enhancement and development. New York: West Publishing Company.

Brady L. \& Kennedy.K. (1999) Curriculum Constraction.Australia. Prentice Hall. Brown, A.L., \& Campione, J.C. (1994). Guided discovery in a community of learners. In K. McGilly (Ed.), Classroom lessons: Integrating cognitive theory and classroom practice (pp. 229-270). Cambridge, MA: MIT Press.

Brown,J.D.1995.The Element of a language Curriculum.Boston:Heinle\&Heinle.

Brown. D.H. 2007. Principle of language learning and teaching.New York.pearson Longman.

Chomot,A \& Kupper.L(1989). Learning strategy in foreign language instruction.Foreign language annalysis, 22 (1), 13-24.

Chou, Peter Tze-Ming. (2010). The internet TESL Journal. Advantages and disadvantages of ESL course books. Vol..XVI, No. 11, November 2010. Retrieved 6 June 2013 from http://iteslj.org/

Cuban, S. 2001. Reading for pleasure. Focus on basics, 5(A), 20-23.

Dechant, E. V. 1982. Improving the teaching of reading. New Jersey: Prentice-Hall.

Dick, Walter, Lou Carey, and James O. Carey. (2005;1978). The Systematic Design of Instruction. $\left(6^{\text {th }}\right.$ ed.). Allyn \& Bacon, pp. 1-12. ISBN 0-205-41274-2.

Endang, (2013) Developing Competency based Training Package For Elementary school English Teacher.Unpublished Dissertation.State University of Makassar. Makassar

Esseff, Peter J. \& Esseff, Mary Sullivan (1998;1970). Instructional development learning system (IDLS). 8 th ed. ESF Press, pp. 12. ISBN 0-205-41274-2.

Jolly, D., \& Bolitho, R. (1998). A framework for materials writing. In Brian Tomlinson (Ed.) Materials development in language teaching. Cambridge University Press: New York.

Hamra, A. (2003). The reading attitude, interest, and habit in reading comprehension of EFL students of Universitas Negeri Makassar. Unpublished doctoral dissertation, Post Graduate of Hasanuddin University, Makassar.

Hamra, A. \& Syatriana, E. 2012. A Model of Reading Teaching for University EFL Students: Need Analysis and Model Design. English Language Teaching. 5(10). Doi:10.5539/elt.v5n10p1. pp.1-11.

Hannafin, D. H. \& Peck, K. L. (1988). The design, development, and evaluation of instructional software. New York: Macmillan Publishing.

Kweldju, S. (2001). Vocabulary and lexicogrammatical units: Graduate students' main problem in reading their textbooks. Linguistik Indonesia. Jurnal Ilmiah Masyarakat Linguistik Indonesia [Scientific Journal of Indonesian Linguistic Society], 1, 35-56.

KTSP information.Retrieved April,29,2012 from http://mbeproject.net/training3.Pdf Lapp, D., \& Flood, J. 1986. Teaching student to read. New York: Macmillan Publishing Company.

Clark, an Longman Dictionary of Geography: ( 1985) Human and Physical. Harlow, Essex, UK: Longman, 1985.S. Lefebvre, Aménagement et planification territoriale, $\ldots$ www.learnquebec.ca/en/content/curriculum/social_sciences/sec_geography/resources/metropolises/conceptsmetr opole.html

Lyman .K. Steil at al. (1983). Effective listening. McGrow . Hill-Companies.

Merriel, M. D; Drake, L: Lacy, M. J.: Pratt J: \& the ID2, Research Group. (1996). Reclaiming Instructional Design. Educational Technology. 36(5), 5-7

Mikulecky,B.S\& Jeffries, L.1996. More Reading Power. California: Anddison-Wesley Publishing company 
Ratna.(2012). An ESP Course design for trou and travel students, aneed analysis from different perspective of tour and travel contex.Unpublished. Proposal Disertation, Makassar. Universitas Negeri Makassar.

Smagorinsky, P. (2001). Rethinking protocol analysis from a cultural perspective. In M. McGroarty (Ed.), Annual Review of Applied Linguistics, 21 (pp. 233-245). New York: Cambridge University Press. Available at http://www.petersmagorinsky.net/About/PDF/ARAL/ARAL2001.pdf

Smith, H. P., \& Dechant, E. V. (1961). Psychology in teaching reading. NJ: Prentice Hall.

Sikki, E. A. A.(2013). Developing competency based training package for elementary school English teacher. Unpublished dissertation. Postgraduate Program. State University of Makassar.

Syatriana, E. (1998). The levels of reading comprehension of the fifth semester students of STKIP YPUP Ujung Pandang. Unpublished undergraduate thesis, STKIP YPUP, Ujung Pandang .

Syatriana E. (2011) Developing a model of teaching of reading comprehension.Makassar

Tomlinson, B. (2012). Materials development for language learning and teaching. Retrieved 16 May, 2013 from http//journals combridge.org. IP address: 131.111.127.89.

Tomlinson, Brian. (1998) Maretials development in Language teaching. Cambridge Language Teaching Library. New York: Cambridge University Press

Vacca, R. T. \& Vacca, J. A. 1986. Content area reading. Boston: Little Brown \& Company. 
This academic article was published by The International Institute for Science, Technology and Education (IISTE). The IISTE is a pioneer in the Open Access Publishing service based in the U.S. and Europe. The aim of the institute is Accelerating Global Knowledge Sharing.

More information about the publisher can be found in the IISTE's homepage: http://www.iiste.org

\section{CALL FOR JOURNAL PAPERS}

The IISTE is currently hosting more than 30 peer-reviewed academic journals and collaborating with academic institutions around the world. There's no deadline for submission. Prospective authors of IISTE journals can find the submission instruction on the following page: http://www.iiste.org/journals/ The IISTE editorial team promises to the review and publish all the qualified submissions in a fast manner. All the journals articles are available online to the readers all over the world without financial, legal, or technical barriers other than those inseparable from gaining access to the internet itself. Printed version of the journals is also available upon request of readers and authors.

\section{MORE RESOURCES}

Book publication information: http://www.iiste.org/book/

Recent conferences: http://www.iiste.org/conference/

\section{IISTE Knowledge Sharing Partners}

EBSCO, Index Copernicus, Ulrich's Periodicals Directory, JournalTOCS, PKP Open Archives Harvester, Bielefeld Academic Search Engine, Elektronische Zeitschriftenbibliothek EZB, Open J-Gate, OCLC WorldCat, Universe Digtial Library, NewJour, Google Scholar

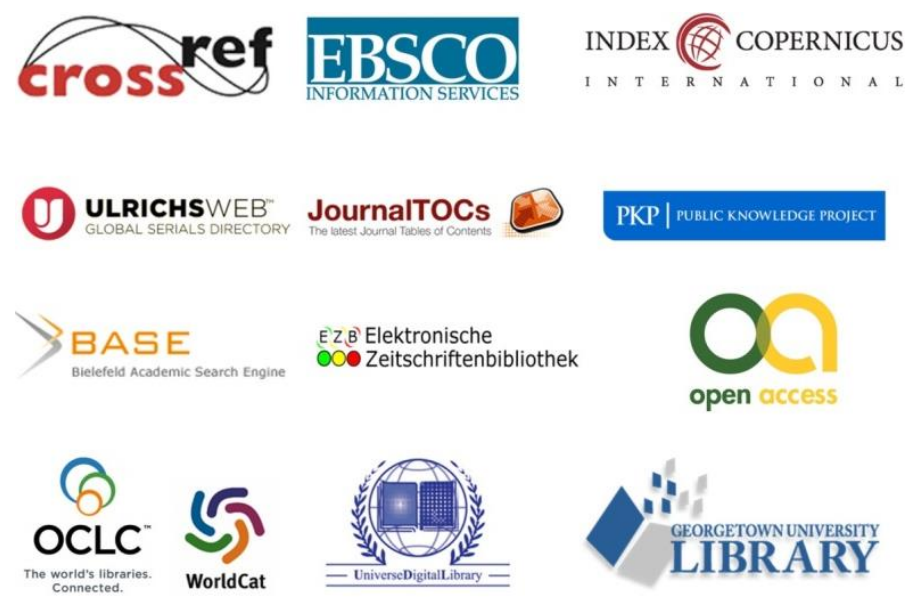

